\title{
Why Care Whether Scepticism is Different from Other Philosophies?
}

\section{Richard Bett}

\section{(2) OpenEdition \\ 1 Journals}

\section{Electronic version}

URL: https://journals.openedition.org/philosant/350

DOI: 10.4000/philosant.350

ISSN: 2648-2789

\section{Publisher}

Éditions Vrin

\section{Printed version}

Date of publication: 24 November 2015

Number of pages: $27-52$

ISBN: 978-2-7574-1141-4

ISSN: 1634-4561

\section{Electronic reference}

Richard Bett, "Why Care Whether Scepticism is Different from Other Philosophies ?", Philosophie antique [Online], 15 | 2015, Online since 01 November 2018, connection on 08 December 2022. URL: http://journals.openedition.org/philosant/350 ; DOI: https://doi.org/10.4000/philosant.350

\section{(c) $(7)(9$}

Creative Commons - Attribution-NonCommercial-NoDerivatives 4.0 International - CC BY-NC-ND 4.0 https://creativecommons.org/licenses/by-nc-nd/4.0/ 


\section{WHY CARE WHETHER SCEPTICISM IS DIFFERENT FROM OTHER PHILOSOPHIES ?}

Richard BETT

Johns Hopkins University

RÉSUMÉ. L'article porte sur la façon dont Sextus, dans les derniers chapitres du Livre I des Esquisses pyrrhoniennes, répond aux argumentations qui tendent à rattacher le scepticisme à diverses philosophies plus anciennes. Après une étude de la nature et des sources de ces argumentations à partir du témoignage de Diogène Laërce et d'autres auteurs, et le constat que bien des questions à ce sujet ne peuvent que rester sans réponse, la majeure partie de l'article est consacrée à l'analyse des contre-arguments avancés par Sextus. Dans presque tous les cas, il apparaît que Sextus s'oppose fermement à tout rapprochement du scepticisme avec d'autres philosophies. Cela est d'autant plus surprenant que la philosophie de l'Antiquité tardive manifeste une tendance marquée à se réclamer de prédécesseurs. L'attitude de Sextus s'explique par son désir de faire comprendre le plus clairement possible que le scepticisme, en réalité, n'a rien d'une philosophie au sens ordinaire du terme. La rareté, chez Sextus, des références à des prédécesseurs nommément désignés, y compris au sein de la tradition pyrrhonienne, peut aussi s'expliquer par le souhait de paraître complètement différent des philosophes tels qu'on les comprend habituellement.

SUMMARY. The article considers Sextus' response, in the closing chapters of book 1 of Outlines of Pyrrhonism, to arguments connecting scepticism with numerous earlier philosophies. The nature and sources of such arguments, as indicated by evidence in Diogenes Laertius and elsewhere, is examined, although it is suggested that much about these questions must remain inconclusive. But most of the paper is devoted to a detailed analysis of Sextus' counter-arguments. In almost every case, Sextus is shown to be very strongly opposed to any rapprochement of scepticism to other philosophies. This is all the more surprising given the increasing tendency in the philosophy of later antiquity to appeal to predecessors. Sextus' attitude is explained as the product of a desire to make as clear as possible that scepticism is not in fact a philosophy at all, in the usual sense of the term. The fact that he makes very little reference to named predecessors even within the Pyrrhonist tradition itself may also be explained by the wish to seem quite different from philosophers as usually understood.

Philosophie antique, $\mathrm{n}^{\circ} 15$ (2015), 27-52 

From at least the Hellenistic period on, ancient Greek philosophical schools routinely and explicitly appealed to predecessors as inspiration for their ideas. For the skeptical Academics of this period to appeal to Plato and Socrates was an obvious move given that Plato founded the school to which they belonged; but the Stoics also appealed to Socrates, and to some extent Plato, even while disagreeing sharply with Plato on a number of issues. ${ }^{1}$ A Stoic debt to Heraclitus is also apparent; while explicit acknowledgement of this by the Stoics themselves is hard to find in the surviving testimonies, we know that the early Stoics Cleanthes and Sphaerus both wrote books about Heraclitus (DL 7.174, 177), which at least suggests an awareness of, and a willingness to admit, common ground. The Epicureans tended to emphasize their own originality to a greater extent; ${ }^{2}$ but both Epicurus himself and Lucretius singled out Democritus as an important forerunner (Epicurus On Nature 34.30 = LS 20C13-14; Lucretius 3.371, 5.622). By the time we get to later antiquity, revived movements of Platonism and Aristotelianism take hold, to which eventually almost all philosophers are attached. And at this point we are far beyond a mere selective acknowledgement of influence; one's whole outlook is defined by one's perceived relation to Plato or Aristotle (or both, for these two movements are by no means entirely distinct $)^{3,4}$.

1. For both the Academics and the Stoics, see the classic Long 1988.

2. See especially Sextus, $M$ 1.3, where Epicurus is reported as repudiating his own teacher Nausiphanes and claiming to be self-taught.

3. On this see Tuominen 2009, chapter 1 .

4. On the increasing appeal in the philosophy of the Greco-Roman world to the authority of a founder figure - who may or may not have been an actual member of the school in question - see Sedley 1997. Also relevant in this context is the thesis of Boys-Stones 2001, that philosophy in the early centuries AD came to be understood as the project of retrieving an ancient wisdom - one that Plato, in particular, was regarded as having already unearthed. 
All this makes it quite noteworthy that Sextus Empiricus, who seems to have lived at a time when this revived Platonism and Aristotelianism were well underway, ${ }^{5}$ takes considerable pains to show that Pyrrhonism is different from other philosophies. He is not even especially eager to admit debts to earlier Pyrrhonists. Pyrrho himself is rarely mentioned in Sextus' pages, and his one explicit remark about how Pyrrho gave his name to the Pyrrhonist tradition is notably stand-offish; he simply says "Pyrrho appears to us to have approached scepticism in an more full-bodied fashion and more manifestly than those before him" (PH 1.7). ${ }^{6}$ Aenesidemus, the founder of the later Pyrrhonist movement to which Sextus himself belonged, also receives comparatively few mentions - seventeen in a total of fourteen surviving books - and several of these are in contexts involving Aenesidemus' interest in or association with the ideas of Heraclitus (a topic to which we shall return), rather than his purely sceptical credentials. Sextus regularly uses phrases such as "we sceptics" - he is not trying to deny being part of a movement - but he is remarkably reticent about acknowledging named predecessors. But the most explicit indication of his bucking the trend of his own time, where situating oneself in the tradition of some earlier authority became more and more important for philosophers, is the final segment of the first book of Outlines of Pyrrhonism (PH 1.209-41); here Sextus discusses several other philosophies, all of them predating Pyrrhonism, and argues that Pyrrhonism is distinct from all of them. My aim in this paper is to try to shed some light on Sextus' motivations in this passage, and more generally on why he seems so eager not to allow his own outlook to be assimilated to those of others before him.

There are six chapters on these other philosophies: on Heraclitus, Democritus, the Cyrenaics, Protagoras, the Academy - with several subdivisions, and including a digression on Xenophanes - and the Empiric school of medicine. Sextus calls them "nearby" (parakeimenai) philosophies

5. Sextus is generally placed in the second century AD. But Jouanna 2009 has argued powerfully for dating him a little later, at the beginning of the third century, primarily on the basis of Galen's silence about him. This is not a new argument, but Jouanna makes clear how unlikely it is that Galen would not have referred to Sextus had they been contemporaries. However, my point in the main text applies even if this is not correct.

6. One might suggest that this is simply a case of Sextus being pedantically Pyrrhonian, avoiding any definite claims about what Pyrrho thought. But in general Sextus has no trouble giving detailed accounts - including, sometimes, variant accounts between which he does not choose - of what other philosophers said or thought. It is clear from Diogenes Laertius' life of Pyrrho that accounts of Pyrrho's sayings and behavior were available, should Sextus have wished to appeal to them. Here, however, he is offering the absolute minimum to explain the label "Pyrrhonian", which reads like a deliberate refusal to appeal to Pyrrho as a predecessor in the sort of way one might expect, given the examples in the previous paragraph. 
and says that he is going to explain the "distinction" (diakrisis) between each of them and scepticism (PH 1.5, 209). Since he is generally so emphatic about the "distinction", one might have expected him to challenge the characterization of these philosophies as "nearby", but he does not do so. The reason, I take it, is that this or related terms were already in use by others as ways of classifying them. Sextus might be uncomfortable with the claim of similarity embedded in the label "nearby"; but he is prepared to use the word in a neutral fashion as a commonly understood means of referring to them.

That some people did think of a number of other ideas, both philosophical and otherwise, as akin to scepticism, and as anticipating it in important respects, seems clear from a passage of Diogenes Laertius' life of Pyrrho (9.71-3), where a considerable number of thinkers and poets are alleged to have been sceptics before their time. ${ }^{7}$ The list begins and ends with Homer, but it includes three of the philosophers considered in the passage of Sextus to which I have referred: Xenophanes, Democritus and Heraclitus (9.72-3). It is also worth noting that all three of these - together with Zeno of Elea, also named by Diogenes as a proto-sceptic (9.72) appear as the subjects of lives earlier in Diogenes' book 9, which ends with the connected lives of Pyrrho and Timon. And another figure treated in book 9 is Protagoras, who also appears in Sextus' group of "nearby" philosophers, though not in Diogenes' own passage explicitly naming sceptical predecessors. Although the ordering of the lives in Diogenes is in large part dictated by actual or supposed teacher-pupil "successions" of philosophers, and we have other records of such "successions" involving many of the philosophers who appear in his book $9,{ }^{8}$ he is not entirely bound by these preexisting sequences, and it is not unreasonable to think that judgements of philosophical closeness may have had played a role in his choices of who to include where; in this case the looming figure of Pyrrho, whose life is by far the longest in book 9, may have had something to do with who else was placed leading up to him. ${ }^{9}$ Besides, the "successions" themselves often relied on judgements of this sort, rather than on any solid biographical data; Diogenes' claim in this book that Parmenides was a pupil of Xenophanes (9.21), which is repeated in numerous other sources, ${ }^{10}$ is a good example.

Thus we have good reason to think that a number of philosophers and other authors were recognized in certain circles as having been to some

7. For an excellent discussion of this passage, see Warren 2015.

8. Clement, Strom. 1.14.64, 2-4; Eusebius, Praep. evang. 14.17.10; pseudo-Galen, Hist. philos. 3 (p. 601 Diels).

9. I have discussed this further in Bett 2015, section I.

10.E.g., Aristotle, Met. 986b21-2 (Aristotle reports this as an opinion held, without himself offering a verdict on it); also the passages cited in $n .8$ above. 
degree forerunners of Pyrrhonist scepticism, and that Sextus is responding to this perception by arguing, for a group of these alleged forerunners that seem to him most significant, that he and his fellow Pyrrhonists are in fact quite distinct from them. ${ }^{11}$ Except in one case, Aenesidemus' claim of a link between Pyrrhonism and Heraclitus (PH 1.210), Sextus does not say who he is disagreeing with, attributing the claims of similarity to an unnamed tines, "some" $(P H 1.215,220,236)$ or remarking that the similarity "is said" (legetai, PH 1.213) or "is thought" (dokei, PH 1.217) to obtain. But the evidence from Diogenes makes clear that views of the kind he is opposing had some currency. There is additional evidence for this in the case of the Academics, whom Diogenes does not mention in this context (or indeed anywhere in book 9); but I will leave aside the Academics until we get to Sextus' treatment of them (section III).

It would be interesting to know whether such views (beyond the case of Aenesidemus and Heraclitus, and again, ignoring for now the case of the Academics) were held by Pyrrhonists - in which case Sextus would be engaging in a dispute internal to the tradition - or whether they came from others: either from those hostile to the sceptics or from doxographers, for whom the classification of philosophies was a major concern, but who were not necessarily attached to any one of them. Diogenes does not say whose idea it was that all the figures he mentions, in the passage I referred to, were proto-sceptics. But can we tell whether or not this idea originated with the sceptics themselves? Although some have thought so, I am not convinced that we can.

Annas and Barnes say that Diogenes ascribes the claim of similarity (in the case of Democritus, but the same would apply at least to several others) to the sceptics themselves. ${ }^{12}$ But the entire passage is introduced non-committally by "some [enioi] say that Homer began this school" (9.71), and the later "according to them" (kat'autous, 9.72), which accompanies the mention of Democritus and others, simply refers back to this "some people"; there is no indication here as to whether these are sceptics or not. Katja Vogt accepts this point, but offers three reasons for thinking that it is in fact the sceptics themselves who are responsible for the comparisons. ${ }^{13}$ The

11. There is of course no necessary opposition between saying that philosopher A was to some degree a forerunner of philosopher B and saying that their philosophies are not the same; hence one might wonder why, with a little nuance, Sextus might not accept certain views about sceptical predecessors of the kind reported in Diogenes. However, as we shall see, Sextus is notably resistant even to claims of similarity between scepticism and other philosophies; as he himself frames the issue, his approach really is in conflict with the one in Diogenes.

12. Annas and Barnes 1994, p. 54, n. 221.

13. Vogt 2015, section 2(i). 
first is that Sextus' account of the distinctness of scepticism refers only to philosophers and medical theorists, whereas Diogenes' passage on the similarities has a good many references to poetry. Since Sextus does not address the poetic quotations, he must not see them as hostile or in need of response, which suggests that they originated in his own school. The second is that Diogenes does address the issue of anti-sceptical challenges, and the sceptic's replies to them, at another place in the life of Pyrrho (9.102-8); but that passage has no clear connection with the passage alleging similarities (even though Democritus appears in both), which suggests that he does not view the latter passage as anti-skeptical in import. The third is that Diogenes explicitly tells us, shortly before the passage about the similarities, that Pyrrho admired Homer (9.67), who has pride of place in the latter passage as the first proto-sceptic (9.71); we might add that he also tells us in the same place that Pyrrho admired Democritus. And this points towards Pyrrho and his early associates having devised the list of poetic and philosophical proto-sceptics.

Although the scenario that Vogt sketches is entirely possible, none of these points seems to me decisive. On the first, Sextus frequently reminds us that Outlines of Pyrrhonism is what its title suggests - a brief overview of the sceptical outlook; hence it would make perfect sense for him to focus only on the claims of similarity that seemed to him most important. And it would not be surprising, given his general orientation, if these centered around philosophical or theoretical concerns rather than poetic remarks of a vaguely sceptical air. Besides, if the poetic parallels originated in the doxographical tradition, Sextus need not have seen them as hostile or deserving of rebuttal; from the fact that they were not devised by the sceptics themselves, it would not follow that he would have to view them as critical in spirit. On the second point, the fact that Diogenes addresses antiskeptical challenges elsewhere does not provide reason for thinking that the similarities were the sceptics' own invention. Diogenes is not always the most organized of writers, and even if the claimed similarities were devised by the sceptics' opponents, there would be no great surprise in their appearing in another part of the life of Pyrrho. In addition, again, there is a further option besides their being of sceptical or anti-sceptical origin; they could have been devised by doxographers who, at least as such, might be entirely neutral as between the sceptics and their opponents. In this case there would be no reason to expect this material to be linked with the antisceptical challenges. And on the third point, Pyrrho's reported admiration for Homer and Democritus would be just as likely to inspire a doxographer as a sceptic to claim similarities between the two of them and scepticism.

Galen does say that "even the Pyrrhonists trace back their school to most ancient men" (In Hipp. De med. off. 1.658.10-12K). But this is a re- 
mark in passing and he offers no details. It has been suggested that there is reason to attribute to Aenesidemus a concern with finding precursors for his own sceptical position. ${ }^{14}$ But apart from the obvious case of Pyrrho himself, and the special case of Heraclitus noted above, the evidence for this is tenuous. It depends on the interesting, but inevitably speculative, claim that Aenesidemus is the source of at least part of Sextus' catalog of positions for and against the existence of a criterion of truth in the first book of Against the Logicians (M 7.46-260) - specifically, the part dealing with the deniers of any criterion, which comes first (M7.48-88). ${ }^{15}$ But even if we accept this claim, the conclusion does not follow. For, as Sextus makes clear $(M 7.46)$, the list of deniers of the criterion is one side of an opposition among dogmatic philosophers concerning the criterion of truth; we are not supposed to identify the sceptics with either side of this opposition. Admittedly, it is possible that Aenesidemus' own position was different; there is reason to think that his version of Pyrrhonism was more focused than Sextus' on denying the existence of various entities, rather than suspending judgement about their existence, ${ }^{16}$ and indeed there may even be some traces of this earlier position in Against the Logicians itself (M 7.26, M 8.1). ${ }^{17}$ But this still does not entitle us to infer that the list of deniers of the criterion was conceived by Aenesidemus as a list of sceptical predecessors. For it is clear from the Ten Modes, which derive from Aenesidemus (M 7.345), that his version of Pyrrhonism also had a large place for assembling oppositions; it is just as likely in this case that he, like Sextus, was interested in laying out both sides of the opposition as that he simply wanted to identify with the negative side.

On this question, then, it seems to me that a properly sceptical suspension of judgement is appropriate. It is quite possible that the

14. Warren 2015, n. 18 and accompanying text.

15. For this claim see Sedley 1992, 25-7.

16. For example, Photius' summary of Aenesidemus' Pyrrhonist Discourses tells us that Aenesidemus denied the existence of signs, causes and ethical ends (Bibl. 170a12-14, 18-19, 30-35). I argue for this way of interpreting Aenesidemus in Bett 2000, chapter 4.

17. As noted by Sedley 1992, 26 n. 11. Sedley also points out that the manuscripts actually contain the sentence "and among these were also the sceptics" at the end of the list of deniers of the criterion (M 7.48). Mutschmann deletes this as contrary to Sextus' purpose, but Sedley wonders whether it should have been retained. Although I have long been suspicious of corrections to the manuscripts of Sextus that are designed to assimilate all his writings to the Pyrrhonism of $P H$, in this case I side with Mutschmann. Again, Sextus has just said that this is an opposition among dogmatists. In addition, the reference to the sceptics has no connection with the following discussion, which is otherwise precisely previewed by the order of the philosophers mentioned. And the remark itself has the feel of a tackedon addition, which is typical of glosses that have found their way into a text. 
Pyrrhonists themselves are behind the passage of Diogenes listing sceptical predecessors, and that Sextus, in arguing that Pyrrhonism is distinct from a number of other philosophies, is going against a view that was current in his own tradition. But this is not the only possibility. I doubt that antisceptics are behind it, because the thrust of the whole passage is to show that the earlier philosophers and poets say things that are sceptical in tone; if it was devised with anti-sceptical intent, one would expect the similarities to be exploited with the aim of showing that the Pyrrhonists were not really sceptical at all, or that they are inconsistent in their scepticism. We cannot be sure that such anti-sceptical strategies were not developed, or that they were not part of what Sextus had in mind in arguing for the distinctness of scepticism; but the Diogenes passage itself does not provide evidence that they were. However, this still leaves the possibility that the Diogenes passage derives from the taxonomic activities of doxographers who were not associated either with the sceptics or with their opponents.

If sceptics were the source, their aim was presumably similar to one of the main aims of dogmatists who appealed to predecessors: to show that their outlook was respectable and possessed of an illustrious pedigree. And if this is the case, Sextus' response must be driven by the thought that pedigree is less important than purity; the association with earlier philosophers, whatever the intentions of those who made it, runs the risk of having the sceptics being considered inconsistent or dogmatic. Avoiding this risk must also be central to his purpose if he is responding to a perception created by the doxographers' classification of philosophies, or for that matter to a critique by anti-sceptics (although in these cases we would have to imagine somewhat different subtexts to his remarks). I shall expand on this point and make it more precise in section IV, after we have looked at the text in some detail.

In any case, it is clear that there were views current to the effect that scepticism was similar to or identical with numerous other philosophies, as well as ideas expressed in various poets. Sextus either does not know or does not care about the poetic comparisons, but he sees the connections made with a number of other philosophies as important enough to refute. How does he go about this?

In general terms, the answer is very simple: in each case Sextus draws attention to definite conclusions that the philosophy being compared with scepticism is prepared to assert, while emphasizing that in contrast the sceptic suspends judgement. In some cases the other philosophy is said (in the view of those whom Sextus is opposing) to be "the same" as scepticism (PH 1.215, 220, 236), while in others it is said to "have a commonality" 
(echein koinonian) with scepticism $(P H 1.213,217)$, which sounds like a weaker claim. It is not immediately obvious whether there is any significance to this difference. If having a "commonality" merely indicates a degree of common ground, one might think that Sextus could accept this while still maintaining that scepticism differs crucially because it, unlike the other philosophy, suspends judgement. Sextus does not explicitly address this possibility one way or the other, but his responses in these cases seem just as relentlessly focused on scepticism's distinctness as in those where the other philosophy is said to be "the same" as scepticism. And in fact, I shall suggest that there is reason to think, in at least one case, that he would be just as unwilling to accept claims of commonality as claims of identity. This only reinforces the impression with which I began, namely that Sextus is strikingly at odds with a standard philosophical approach in his time. It also puts into sharper focus the question of his purposes in this part of the work.

The first allegedly "nearby" philosophy considered is that of Heraclitus (PH 1.210-12). This is introduced with neither a claim of "commonality" nor one of identity; having said that the philosophy of Heraclitus will be the first to be considered ( $P H$ 1.209), Sextus launches immediately into his response, saying "that this is different from our approach is clear" $(P H$ 1.210). As we saw, Heraclitus was among those considered proto-sceptics by whoever are behind the list in Diogenes Laertius (9.73). But while some of what Sextus says in this chapter would no doubt serve to address their view, his explicit target is just one person - his own Pyrrhonist predecessor, Aenesidemus - and for a very specific reason. Aenesidemus is said to have held that scepticism is a route (hodon) to the Heraclitean philosophy, because the idea that opposites appear to apply to the same thing "precedes" (prohegetai) the idea that they actually do apply to the same thing; the sceptics adhere to the first idea and Heraclitus to the second, and the one can lead to the other.

There is room for considerable debate about what exactly Aenesidemus was suggesting. ${ }^{18}$ But one thing is clear. To say that scepticism is a route to the philosophy of Heraclitus does not imply that one wishes to follow that route oneself; thus we do not need to suppose that Aenesidemus became or intended to become a Heraclitean (though this has sometimes been supposed). ${ }^{19}$ The term prohegetai, "precedes", seems to suggest that acceptance of the appearance of opposites applying to the same thing is somehow a

18. Significant recent treatments are Polito 2004, Pérez-Jean 2005, Schofield 2007; a brief sketch of the main issues is Hankinson 2010, section IV.

19. E.g. Brochard 2002, livre III, ch. IV. 
precondition of coming to accept their reality; ${ }^{20}$ but this still does not mean that Aenesidemus himself wanted to move from the first step to the second - a necessary condition is not the same as a sufficient condition. Nonetheless, it does look as if Aenesidemus saw a significant point of contact between scepticism and Heracliteanism - a "commonality", to use the term Sextus himself uses in some other cases; and the same is suggested by a repeated phrase elsewhere in Sextus, Ainesidemos kata Herakleiton (M7.349, 9.337, 10.216). This at first appears to mean "Aenesidemus according to Heraclitus", but that is of course impossible. ${ }^{21}$ It is hard to know exactly how to translate it; Malcolm Schofield has suggested that it is equivalent to "Aenesidemus' version of Heraclitus", and R. J. Hankinson has seen it as shorthand for a phrase of the form "Aenesidemus said that, according to Heraclitus...".22 Either way, the phrase appears in contexts where it looks as if Aenesidemus was examining or explaining Heraclitean ideas - without necessarily endorsing them, but apparently exhibiting a special interest in them.

But Sextus will have none of this. His response in the chapter we are considering is twofold. On the one hand, he points out that Heraclitus says many things dogmatically; the point is made in general terms at the outset (PH 1.210) and is later illustrated, one of the examples being precisely the end-point of the "route" to Heracliteanism that Aenesidemus is said to have referred to - that opposites do not merely appear to apply, but do in fact apply (byparchein), to the same thing ( $P H$ 1.212). On the other hand, he urges that there is nothing specially sceptical about the notion that opposites appear to apply to the same thing; this is just common knowledge or more precisely, a common "preconception" (prolepsis) - which sceptics, Heracliteans or any other philosophers can make use of as they please ( $P H$ 1.211). Thus there is no reason to regard scepticism in particular as making a contribution (Sextus' word is synergei, PH 1.212) towards the Heraclitean outlook; returning in conclusion to Aenesidemus' notion of a "route", he calls the very idea absurd ( $P H$ 1.212).

20. For other examples of this usage in Sextus, see $M 7.263, M 8.60$; for an example outside Sextus, see Epictetus, Diss. 3.7, 6.

21. At least, if this Heraclitus is the Presocratic Heraclitus of Ephesus. But this seems clearly to be the Heraclitus at issue in $P H 1$, and Sextus never suggests that he has more than one Heraclitus in mind.

22. Schofield 2007, 272 n. 3; Hankinson 2010, 116. Pérez-Jean 2005, 13-16 does not come down in favor of any single definitive reading of the phrase; however, like these other two, she sees it broadly as indicating Aenesidemus as an interpreter of Heraclitus - which might or might not be accompanied by agreement with him on some points. See also Viano 2002. 
The vehemence of Sextus' disagreement with the founder of the Pyrrhonist movement to which he himself belonged is more than a little surprising. And here at least, even if nowhere else, we have Sextus opposing a rapprochement with another philosopher that originated within his own school. What is also remarkable is the comprehensiveness of his desire to avoid all possible connections with this other philosophy. Neither Sextus' own report in this chapter nor any other evidence gives us reason to think that Aenesidemus took Heraclitus to have been a sceptic (as did the people whose views are reported in Diogenes' list of proto-sceptics); all we need to suppose is that he was interested in some themes in Heraclitus that resonated with his own concerns. There are indeed many fragments of Heraclitus, usually grouped by scholars under the heading of the Unity of Opposites, that could be said to express the idea that opposites apply to the same thing, and one could well imagine that this kind of material could have been useful to Aenesidemus in compiling his Ten Modes. To judge from the occurrences in Sextus of the phrase Ainesidemos kata Herakleiton, his interest in Heraclitus extended beyond this; the topics at issue there are the location of thought (dianoia, M 7.349), the relation between whole and part ( $M$ 9.337) and the nature of time ( $M$ 10.216). But this too carries no implication as to his having adopted a Heraclitean position or considered Heraclitus himself to have been a sceptic. Why, then, is the Heraclitean connection so objectionable to Sextus? Merely establishing that Heraclitus was not a sceptic is not enough for him. That would be compatible with acknowledging the limited common ground implied in Aenesidemus' remark about the "route" to Heraclitus' philosophy; but Sextus is eager to banish the whole idea of the "route" as well. It looks as if he simply wants no association with Heraclitus at all. Or, to use again his own language in the chapters to follow, it looks as if he wants to rebut not only the notion that Heraclitus' philosophy is "the same" as scepticism, but even the suggestion that it "has a commonality" with scepticism - or, for that matter, that it is really a "nearby" philosophy, despite his willingness to use this term in introducing this part of the book.

When he gets to the next philosophy, that of Democritus ( $P H 1.213$ 14), Sextus calms down a little. Democritus is said to "have a commonality" with scepticism, and the reason is that he, like the sceptics, makes use of oppositions such as that honey appears sweet to some and bitter to others. This is then said to lead him to use the phrase ou mallon, "no more" - such as in "honey is no more sweet than bitter" - a phrase that, according to the proponents of this view, "is sceptical" (skeptiken ousan, PH 1.213). Sextus' first response is that ou mallon, though certainly a phrase used by sceptics, is not sceptical in the hands of Democritus; he uses it to deny that either alternative is the case, whereas the sceptics use it to express indecision as to 
whether both alternatives are the case or neither is ${ }^{23}$ in the former usage it is part of a dogmatic assertion, and that is what the sceptic avoids. The thought behind Democritus' reported use of the phrase is clearly that expressed in the famous fragment "By convention color, by convention sweet, by convention bitter; in reality atoms and void" (Galen, On Medical Experience 15.7; DK 68B125); on this view honey is not in reality either sweet or bitter ${ }^{24}$ and the "no more" statement would be saying precisely this. It is no accident that Sextus immediately follows his first response with a reference to the other half of this fragment, "in reality atoms and void", claiming quite reasonably that this is an assertion about how things really are, and hence quite different from anything that the sceptics would be prepared to say (PH 1.214). In closing Sextus comments that this is so "even if he [Democritus] begins from the lack of uniformity [anomalia] among apparent things", which is at least an implicit recognition that there is some "commonality" between Democritus and himself. Still, despite this more conciliatory tone, the overriding focus is on the differences rather than the similarities.

The same is even more clearly true in the case of Protagoras, who is the other thinker said (on the interpretation Sextus is scrutinizing) to exhibit a "commonality" with scepticism ( $P H$ 1.217). Here there is no explicit acknowledgement of common ground, and there is at least an implicit rejection of the argument for the claim of "commonality". This argument appeals to Protagoras' famous statement "A human being is measure of all things"; this statement shows, we are told, that "he posits only the things that are apparent to each person, and in this way he brings in relativity" (PH 1.216). Sextus' response is that if we spell out more fully what the "measure" doctrine involves, we will see that, on the contrary, it commits Protagoras to dogmatic claims about how things actually are, which makes

23. It is at first sight surprising that Sextus does not mention the possibility that one of the two alternatives is the case, with further indecision as to which one. Presumably this is because he is responding to Democritus, who says that "neither" is the correct answer. Sextus' reply is: yes, it could be neither, but it could just as well be the opposite (that is, both) and this is a genuinely sceptical use of ou mallon, which is all he needs for the current purpose.

24 . To call honey sweet only "by convention" may seem strange; surely it tastes sweet (to people whose sense organs are in a normal state) regardless of our conventions. The explanation of this that I find most satisfactory is that the convention consists in saying unqualified things like "honey is sweet", which implies (or so it might well be thought) that one takes sweetness to be a property of honey itself - that is, of the collection of atoms and void that we call honey - rather than what it really is, namely an effect of the interaction of these atoms and void with the atoms and void that constitute ourselves. For this reading see Furley 1993, 77-8. 
his position quite different from scepticism (PH 1.217-19). According to Sextus' reading of the doctrine, the world is variable, and is in itself such as to be, on any given occasion, any of the ways it appears to some perceiver. ${ }^{25}$ Hence Protagoras does not merely posit appearances, as alleged by the people who said he had a "commonality" with scepticism; every appearance is also (on the particular occasion on which it presents itself) the way things really are. This interpretation seems to derive ultimately from Plato's Theaetetus, specifically the elaborate theory of perception that is presented as the ontological underpinning of the "measure" doctrine (156a-157c), although there are intrusions of post-Platonic terminology notably "matter" (byle) as the name for the changeable underlying reality and a number of examples are borrowed from the fourth of the Ten Modes (PH 1.100). In any case, the true meaning of the "measure" doctrine is said to be that "a human being is the criterion for the things that there are; for all the things that appear to human beings also are" (PH 1.219). Hence Protagoras is committed to any number of assertions about how things actually are - whereas the sceptics regard these matters as unclear and suspend judgement about them.

Between the chapters on Democritus and Protagoras Sextus includes a brief chapter on the Cyrenaics ( $P H$ 1.215). The Cyrenaic view is declared by some to be the same as scepticism on the ground that "it too says that we apprehend only the ways we are affected" ${ }^{26}$ It is not clear whether Sextus accepts the point implied in the word "too" (kai), that the sceptics themselves claim that we "apprehend the ways we are affected"; in fact I think he would be well advised to avoid (as he generally does) the dogmatic notion of "apprehension" (katalepsis) altogether in describing the sceptical outlook. ${ }^{27}$ In any case, we do not need to read him here as doing more than reporting the reason given by those who made the claim of identity. His response to the claim is twofold. First, he says that the Cyrenaics have a different end from the sceptics - namely, pleasure rather than tranquility and moreover they are described as "strongly asserting" (diabebaioumenos) that this is the end, rather than the much more tentative way in which the

25. Sextus says that "the logoi of all the things that appear are underlying in the matter" (PH 1.218). As Annas and Barnes 1994, 56, n. 234 point out, it is not clear exactly what logoi means here. But the general idea must be that this matter has the capability of transforming itself so as to have in reality any of the characteristics that it appears to have to someone on a particular occasion.

26. I follow Annas and Barnes 1994 in retaining the mss. reading katalambanein, (supported by the medieval Latin translation comprehendere), rather than altering to katalambanesthai as do several editors; the Greek is a little awkward but not impossibly so. "Ways we are affected" translates pathe.

27. On this see O’Keefe 2011. 
sceptics elsewhere propose their end. ${ }^{28}$ And second, the Cyrenaics do not suspend judgement about external things, but make the definite assertion (apophainontai) that they have an inapprehensible nature; this makes them, in the terminology of modern scholarship, negative dogmatists rather than sceptics. The Cyrenaics may have interesting resemblances to the figure of the sceptic in modern philosophy. ${ }^{29}$ But Sextus has no trouble in showing that his form of scepticism, centered as it is around suspension of judgement, is clearly distinct from their philosophy.

\section{III}

Following the chapter on Protagoras is the one on the Academics, which is the longest and most complicated of all of them. In this case we have evidence, quite distinct from that considered in section I, that shows a debate concerning whether or not their philosophy is the same as Pyrrhonism; we should begin by considering this, since I left it aside earlier in the interest of simplicity. First, we should note that Aenesidemus founded the later Pyrrhonist movement in large part as a reaction against the Academy, of which he was originally a member. ${ }^{30}$ The chapter of Photius that contains a summary of Aenesidemus's Pyrrhonist Discourses has much to say about the failure of the Academics to maintain a genuinely sceptical - that is, suspensive - attitude; they are several times said to make definite assertions, and in this respect to be no different from their supposed rivals, the Stoics (Bibl. 169b36-170a11, 170a14-17, 22-38). The charge is said to apply especially to the Academy of Aenesidemus' own day (170a1415), but it is issued quite generally. From Photius' account it looks as if this topic occupied a considerable portion of the first book of Aenesidemus's work. Since this distancing of the Pyrrhonists from the Academics was an important impetus for the Pyrrhonist movement itself, I assume (though I do not think it can be absolutely proven) that the idea that the Academics'

28. "Up to now we say that the sceptic's end is ataraxia ..." (PH 1.25). Both the "up to now" (achri nun) and the restriction of the end to the sceptics protect Sextus from dogmatism. The end is put forward as a report of the sceptics' own experience ( $c f . P H 1.4)$ - this is what they have in fact pursued - not as what human beings in general should or naturally do pursue, which is how the telos is normally understood in ancient Greek ethics, or even as what the sceptics are committed to pursuing in the future. (PH 1.12 does suggest that Sextus thinks philosophers in general aim for ataraxia, but his actual specification of the telos makes no mention of anyone besides the sceptics themselves.)

29. Although here too the similarities should not be exaggerated; on this see Bett forthcoming a.

30. On the last point see Photius Bibl. 169b32-5. This reading of the passage was challenged by Decleva Caizzi 1992, but the challenge was refuted by Mansfeld 1995. 
philosophy was the same as that of the Pyrrhonists did not originate within Pyrrhonism, at some point between Aenesidemus and Sextus. ${ }^{31}$

But others clearly were prepared to maintain this, including in the period immediately before Sextus. Aulus Gellius reports "an old question, dealt with by many Greek writers, whether there is any difference, and how much, between the Pyrrhonian and Academic philosophers" (11.5.6). Gellius does not express a final opinion on this himself, saying that although there is a lot in common between the two schools, "they have been thought" (existimati sunt) to differ in that the Academics maintain as a definite conclusion that nothing can be known, whereas the Pyrrhonists suspend judgement on this question. As we shall see, this is one of the main points Sextus uses to distinguish himself from some Academics, and there is other evidence for this reading of the Academics (e.g. Cic. Acad. 1.45). Gellius does not tell us who thought this, nor who, if anyone, opposed the view that they differed in this way. Since he has just mentioned Favorinus (11.5.5), since Favorinus elsewhere figures in Gellius as both source and character, and since Gellius is not otherwise particularly interested in scepticism, the chances are good that he gets his information on this topic from Favorinus; but that does not tell us whether Favorinus endorsed the idea of the difference or opposed it. However, what Gellius tells us in the immediately preceding passage is that Favorinus wrote a work in ten books called Pyrrhonian Modes; Diogenes Laertius also tells us of Favorinus' interest in the Modes (9.87). Since Favorinus was a self-professed Academic, this tends to suggest that he saw the two schools as more similar than different; ten books would be a lot to write unless one saw something valuable and congenial in one's topic, and the title is simply Pyrrhonian Modes - not Against the Pyrrhonian Modes or the like, as one might expect if the work was a polemic. ${ }^{32}$ In this case the claim of difference would be one that he recorded but did not agree with. Indeed, for reasons of this sort some have

31. Hostility to the sceptical Academy (as we now call it) is also evident in the early Pyrrhonist period. Timon, Pyrrho's disciple, is openly scathing about Arcesilaus (DL 4.42). He does elsewhere seem to allow that Arcesilaus borrowed something from Pyrrho (DL 4.33). But in the same fragment he pictures him as also indebted to Menedemus and Diodorus; his point, I take it, is that the resulting mixture is a disaster from the Pyrrhonist perspective.

32. Gellius' information has been suspected; for a defense of both his text and his credibility, see Holford-Strevens 1997, 213 n. 96. Note also that Plutarch, Favorinus' teacher, wrote a work On the Difference Between Pyrrhonists and Academics (Lamprias Catalog 64). But that title does not tell us whether he saw the difference as significant or as exaggerated by others; and in any case, we need not assume that Favorinus always thought the same as his teacher. 
even seen Favorinus as Sextus' opponent in his chapter on the Academics. ${ }^{33}$ I tend to doubt this, if only because Sextus in general, for whatever reason, does not seem to engage directly with the philosophy of his own time. ${ }^{34} \mathrm{But}$ if I am right about Favorinus' stance, it would admittedly be an instance of the kind of view Sextus is anxious to resist. In any case, the extent of the discussion on this question makes clear that the view that the two philosophies were essentially the same had a continuing attraction for some.

Sextus' response distinguishes between several phases of the Academy, and treats each of them separately. ${ }^{35} \mathrm{He}$ begins with Plato, acknowledging that there is a range of interpretations of him of varying degrees of dogmatism (PH 1.221). As he says, the only one that he needs to refute is the one that says that Plato is "purely sceptical" or "aporetic"; any interpretation that attributes to Plato some degree of dogmatism has already conceded that he is not sceptical ( $P H$ 1.222). And the response to the "purely sceptical" interpretation is that Plato makes a great many definite assertions. ${ }^{36}$ If he assents to these, he is clearly not a sceptic; and if he puts them forward as more plausible than their alternatives, he is not adhering to the Pyrrhonist posture of seeing both (or all) the alternatives as of "equal strength" (isostheneia). ${ }^{37} \mathrm{He}$ concedes that there are parts of Plato's work that have a sceptical aspect $(P H 1.223,225),{ }^{38}$ but insists that unless one is sceptical through and through, one is a dogmatist; holding definite views, or taking certain things to be plausible, on even one subject disqualifies one from consideration as a sceptic. As in the case of Democritus, there is an

33. Holford-Strevens 1997, 212-17; Ioppolo 2002, 66-70.

34. On this, see further Bett forthcoming $b$.

35. Ioppolo 2009, 32-3 argues that this division is strategic, dictated largely by the need to separate Arcesilaus from the rest. See chapter 1 of this work for a much more detailed account of this chapter of Sextus than I can provide here.

36. One might better say that characters in Plato's dialogues make these assertions (except, of course, in the Letters, where the ancients were more ready than most modern scholars to find the voice of Plato). But Sextus agrees with the many people through the ages who have seen Plato as to some degree speaking through his characters.

37. As we shall see shortly, a similar point is made about the New Academy of Carneades, although in their case a response may have been available. By contrast, there is no reason to think that Plato had any special interest in avoiding taking things to be true, whether definitively or tentatively.

38. Sextus has in mind the dialogues that modern scholars sometimes call "aporetic". These are referred to as the "gymnastic" or "training" works ( $P H 1.221)$, the idea being that they are designed to introduce people to philosophical discussion in preparation for the works that involve positive doctrines. This terminology was not invented by Sextus; see, e.g., DL 3.49, in a neutral classification of different kinds of Platonic dialogues. But it suits his purposes nicely in so far as it suggests that the sceptical-looking parts of Plato are really just preparatory to, and hence less serious than, the non-sceptical parts. 
admission of some common ground, but this is framed in such a way as to maximize the impression of difference. ${ }^{39}$

The idea that scepticism must be complete if it is to count as scepticism at all is then further illustrated by the case of Xenophanes as interpreted by Timon ( $P H$ 1.224-5). Xenophanes is presented as regretting his lapse into the holding of doctrines and his only partial adherence to a sceptical outlook; Sextus' point, again, is that partial adherence is no adherence, and he concludes this digression by referring back to the case of Plato $(\mathrm{PH}$ 1.225). The digression is unexpected in that Xenophanes had nothing to do with the Academy. But the verses of Timon that he cites provide a vivid image of what it is like to be only partially (that is, not really) sceptical, ${ }^{40}$ and also give Sextus an excuse to check off one more philosopher - in this case, one for whom the early Pyrrhonist Timon had some degree of respect - as clearly distinct from the sceptics.

Sextus now turns to the "new" Academy - that is, the Academy of Carneades and Clitomachus - and argues on two grounds that its outlook is different from scepticism ( $P H$ 1.226-31). First, these Academics assert as a definite conclusion that everything is inapprehensible, which makes them negative dogmatists. ${ }^{41}$ Second, they treat some appearances as more plausible or persuasive (pithana) than others, which already involves them in the holding of opinions. It is not clear that either of these claims is fair to the Academics. ${ }^{42}$ While we have good evidence that Carneades argued that nothing can be apprehended, or that there is no criterion of truth including from Sextus himself (M 7.159-65; see also, e.g., Cic. Acad.2.28) it is not obvious that he meant to assent to this conclusion, as opposed to offering it as a counter-balance to the positive arguments of others on the criterion, especially the Stoics. ${ }^{43}$ On the second point, Cicero reports that Clitomachus (following Carneades) made the case that one could follow impressions - that is, make use of them for the purposes of action and

39. At one point Sextus compares his own view on Plato's relation to scepticism with that of Aenesidemus (PH 1.222); unfortunately the text is corrupt, so we cannot simply read what he said Aenesidemus' position on this was. I have argued elsewhere that Sextus is here agreeing with Aenesidemus (Bett 2006); see also Spinelli 2000, Bonazzi 2011. I therefore do not treat this as a case of intra-Pyrrhonist dispute; but for another reading see Ioppolo 2009, 52-74.

40. What it would mean to be properly sceptical may not be precisely the same in Timon's estimation and in Sextus'. But Sextus' reading of Timon, according to which Xenophanes is portrayed as partly but not wholly achieving the ideal attitude, seems plausible.

41. The same point was made in the very first chapter of the work $(P H 1.3)$ as Sextus was introducing scepticism and its rivals.

42. On this, see further Ioppolo 2009, 35-42.

43. On this point see, e.g., Thorsrud 2010, section IV. 
discussion - without assenting to them in any objectionable sense; one way of reading this is that their persuasiveness consists simply in their psychological influence, and one need not endorse the truth of any proposition - which is what the objectionable kind of assent would be - in order for them to have this effect (Acad. 2.104). ${ }^{44}$ Some have found this account unintelligible..$^{45}$ But since Sextus himself allows that the sceptics follow or yield to some impressions without holding opinions, and is prepared to borrow the term "persuasive" to refer to these ( $P H$ 1.230), it does not look as if he would agree. And so it is not clear why he should not allow that the Academics' appeal to persuasiveness without assent (at least, assent of a sort that would compromise them) can be understood in the same way - instead of insisting, as he does, that they follow their persuasive impressions with a "strong inclination" (prokliseos sphodras, PH 1.230) that commits them to holding opinions. There is, then, at least a possibility that Sextus is forcing the evidence so as to maximize the sense of a difference between himself and the New Academy.

Sextus ends the chapter with a brief look at the late Academics Philo and Antiochus (PH 1.235). Here we need not doubt that the distinctions he draws between their philosophies and his own have some basis; there is plenty of other evidence that Philo was not a sceptic in anything like Sextus' terms and that Antiochus was not a sceptic in any sense. ${ }^{46}$ But before these Sextus spends a little time on Arcesilaus, the figure who is generally regarded as having turned the Academy in a sceptical direction, and this is more interesting.

Sextus begins by saying that Arcesilaus' outlook and his are virtually the same (mian einai schedon, PH 1.232); in contrast with the other Academics discussed in this chapter, Arcesilaus is said to suspend judgement about everything, and this is supported by some points on which he differs from the new Academy as Sextus has just depicted it. ${ }^{47}$ This is remarkable seeing that the aim of this whole section of the book has been to explain the differences between scepticism and the allegedly "nearby" philosophies; in the

44. Frede 1997 and Bett 1990 include versions of this kind of interpretation.

45. See Thorsrud 2010, 73-4; Perin 2013, 321-2.

46. A good brief review of the evidence is the "Introduction" to Brittain 2006, especially section II. For Philo see also Brittain 2001; for Antiochus see Sedley 2012.

47. Sextus' comment that Arcesilaus "absolutely seems to me to share in [koinonein] the Pyrrhonists' words [logois]" seems to mark a closer similarity than the one claimed by the other side in the case of Democritus and Protagoras: that they "have a commonality" (koinonian) with scepticism. In addition to the "absolutely" (panu), koinonein, "share in", seems to suggest a comprehensive overlap, whereas koinonia is more suggestive of individual features in common. But however this may be, the key point is what Sextus says next - that the two outlooks are almost the same. 
case of Arcesilaus, Sextus seems not to find anything relevant to say. However, he immediately goes on to mention two other interpretations that put Arcesilaus in a different light. One is that while they say much the same things, Arcesilaus says them in a dogmatic register, so that on his view suspension of judgement is by nature a good thing and assent by nature a bad thing ( $P H$ 1.233). The other is that Arcesilaus was really a secret Platonist and used sceptical argumentation as a test to see who was ready to receive the true philosophy of Platonism $(P H 1.234)$ - much as, on a view that we glanced at earlier, some of Plato's own philosophical activity was designed for training rather than indoctrination and for this reason had a sceptical appearance. ${ }^{48}$ Sextus does not say that he accepts either of these other interpretations, but nor does he explicitly repudiate them; as a result, the status of Arcesilaus vis-à-vis scepticism is left somewhat unclear.

I close this section with a very few remarks on the final chapter on medical Empiricism. Here Sextus, himself an Empiricist, appears to reject an identification between scepticism and the Empiric school ( $P H$ 1.236). He makes this conditional on the Empiricists affirming that unclear things are inapprehensible, which would mean that they were negative dogmatists. But he leaves this on the table as an unanswered accusation, and instead spends several sections explaining why another medical approach, Methodism, would be more appropriate for a sceptic ( $P H$ 1.237-41). The issues here are very difficult and cannot be discussed on this occasion. ${ }^{49}$ I will simply point out that the Methodist school of medicine, like Arcesilaus, is a case where Sextus allows a similarity - "kinship" (oikeiotes) is his word (PH 1.241) - and does not hasten to diminish it by emphasizing differences. It is a qualified kinship (ouch' haplos), but it is greater than that of any other medical school, and there are no stated considerations that undermine it.

\section{IV}

Let me try to sum up the results of this survey. Sextus is in general extremely resistant to claims of identity or even similarity between his brand of scepticism and other philosophies. This is true even when the common ground was suggested by an earlier Pyrrhonist, as we saw in the case of Aenesidemus and Heraclitus. In addition, throughout his work he is notably reticent about appealing to predecessors within his own Pyrrhonist tradition. In both respects Sextus is strikingly different from the sceptical Academy. As I mentioned at the outset, these Academics look back to Socrates and Plato, and this is no surprise; but they also appeal to numerous

48. See again n. 38 .

49. A good recent discussion is Allen 2010. 
Presocratics as predecessors. ${ }^{50}$ And much of the later history of the sceptical Academy revolves around a debate between rival factions, each claiming to be the true heirs of Carneades. ${ }^{51}$ Sextus, however, seems to go out of his way to emphasize that he and his anonymous Pyrrhonist friends are quite different from everyone else. What might explain this seemingly extreme attitude?

The simplest approach to this question, I think, is to take him at his word: Sextus considers Pyrrhonist scepticism to be an entirely distinct kind of enterprise from every other philosophical movement, and he thinks that this point cannot be overemphasized. Another way to express this point is that scepticism is not a philosophy at all, at least as that term is frequently understood. Although Sextus opens Outlines of Pyrrhonism by distinguishing three main kinds of philosophy, of which scepticism is one $(P H$ 1.1-3), and although he sometimes speaks elsewhere of the "sceptical philosophy" (e.g. PH 1.4, 5), he also frequently speaks of non-sceptical philosophy as "so-called [kaloumenes or legomenes] philosophy" (e.g., PH 1.6, 18), which carries, I think, two implications: first, that these philosophers claim to be doing something that they in fact fail to do, and second, that in this understanding of what philosophy is or should be, Sextus himself has nothing to do with philosophy. Their pretention, I take it, is that they have succeeded, at least to some degree, in discovering and describing the true nature of things in a systematic way; and it is perhaps no accident that the phrase "so-called philosophy" occurs exclusively in passages where one or more of the three main parts of this systematic enterprise (that is, logic, physics and ethics) are the topic of discussion. (Sometimes, too, the parts themselves are referred to as "so-called", e.g., PH 3.167, 278.) For convenience let us call this philosophy. This is not, of course, the only conception of philosophy, which is why Sextus does not simply reject the term as applied to scepticism; but it is one that might well be considered to be dominant in the Hellenistic period and later antiquity. It is this conception that the Peripatetic Aristocles has in mind when he says of Pyrrhonism (in a phase that predates Sextus but postdates Aenesidemus):52 "I do not think it should even be called a philosophy, since it does away with the startingpoints of philosophizing" (in Eusebius, Praep. evang. 14.18.30). Assuming the same conception of philosophy, I think that Sextus' reply would be "exactly!" - and that this gets to the heart of what he is concerned with in these chapters. If that is what philosophy is, at least according to a

50. On this see Brittain and Palmer 2001.

51. For a survey of this history see Lévy 2010.

52. Aristocles' dates are controversial, but he seems to speak of Aenesidemus as relatively recent (in Eusebius, Praep. evang. 14.18.29). 
widespread conception, then it is understandable that he would want to make clear that he is doing something fundamentally different, and therefore that he would want to reject all associations with those who do qualify as philosophers in that conception. ${ }^{53}$

Now, as I noted at the beginning, in the period leading up to and including Sextus himself, philosophers so understood tended more and more to identify themselves with founder figures from the past; the appeal to some earlier authority was an important part of how one legitimized one's positions. Thus, if Sextus wants to distance himself from all associations with philosophy, this may point to a further explanation for his rejection of claims concerning predecessors to his own school. It is not just that the comparisons to which he is responding were made between scepticism and philosophers $\mathrm{D}$; the very appeal to predecessors may itself have come to be connected, in his mind at least, with the notion of doctrinal succession, and hence with philosophyD. ${ }^{54}$ This may also explain why he says so little about his own predecessors within the Pyrrhonist tradition; perhaps the very idea of a tradition of thinking, with important founding figures, carries too much of an implication of the transmission of doctrines - or could too easily be understood in that way by others not willing to examine what Pyr-

53. One might object that if Sextus means to distinguish two different conceptions of philosophy, he ought to have made this clear and explained what each conception amounts to. Now first, as I have noted, Sextus does use the term "so-called philosophy" to mark the sort of approach to the subject that he wants nothing to do with; the term itself indicates that he considers philosophy of this kind a hopeless quest, and the contexts in which he invokes the term send a strong signal that this is due to its constructive and systematic ambitions. By contrast, he is prepared to use the unqualified term "philosophy" to apply to scepticism and dogmatism equally. While this perhaps does not tell us everything we might wish to know about the distinction he is pointing to, it is by no means wholly opaque. But second, I think there are limits to how much clarity Sextus actually wants on this topic. I am the one who, for the purpose of elucidating his intentions on the matters we have been concerned with, wishes to mark a clear distinction between two conceptions of philosophy present in his work, and I hope I have given a tolerable explanation of at least the one he repudiates. Sextus himself, I believe, is deliberately being somewhat less forthcoming about what does or does not count as philosophy, with a view to prompting further reflection, and ideally suspension of judgement, about that very question. I have said a little more about this in Bett 2013, esp. p. 392, 401-3.

54. I do not mean to imply that there is anything inherently dogmatic about the appeal to predecessors; the idea is just that exposure to numerous examples of dogmatists who did appeal to predecessors could have led to such an association for Sextus - or at least, as I go on to suggest, to a worry that others might read him with such an association in mind. I also do not claim to have direct evidence for this contention; I merely point to its ability to explain some things that need explanation. 
rhonism actually is. ${ }^{55}$ If there is anything to this suggestion, then the point with which I began - Sextus' position as an outlier with respect to the appeal to predecessors - should not really be surprising after all. It is integral to his conception of what he is doing that he should wish to go conspicuously in the opposite direction to other philosophers - or rather, in the opposite direction to philosophers $s_{D}$, among whom he very deliberately does not wish to count himself. ${ }^{56}$

It may seem surprising that Sextus should extend this attitude even to the Academy, which was generally considered to have been sceptical in the Hellenistic period. However, as I said, the Academy, including in its sceptical period, has no trouble with appealing to predecessors, Plato prominently included. Both because he has legitimate reason to consider Plato (at least in some moods) as a philosopher , and because to him the appeal to predecessors may itself have the feel of philosophy, this could have prompted Sextus to paint all of them, or almost all, as quite distinct from the Pyrrhonists. Even in the one case, Arcesilaus, where he cannot avoid admitting that there is a lot of common ground, he will not simply say so, but puts this alongside non-sceptical interpretations of his thought and hence creates uncertainty about what he has just said. It is also interesting that he treats Arcesilaus out of chronological order, after the New Academy instead of before. The effect is to reinforce the sense of the New Academy, which now comes immediately after Plato, as following in Plato's footsteps - since in his portrayal they, like Plato, rely to a large extent on persuasiveness or plausibility - and to make Arcesilaus look more like an isolated figure not immersed in a tradition. If being part of a tradition itself has a suspect air for Sextus, this makes good sense in light of his qualified willingness to acknowledge Arcesilaus as a kindred spirit.

55. This may also be a factor in Sextus' care in explaining the sense in which Pyrrhonism is a school (bairesis, $P H$ 1.16-17). What he actually says is that it is not a school if that implies the acceptance of doctrines, but it is a school if that just means a certain method or way of life (agoge). This was not just his idea; Diogenes also says something similar about the senses in which Pyrrhonism is or is not a school (1.20). But the notion of a school might also suggest a succession of thinkers over time who had made a certain set of intellectual commitments; if so, Sextus would have an additional reason to worry that calling Pyrrhonism a school, without being highly specific about what that means, might give people the wrong idea.

56. I mentioned earlier that Sextus does not seem to engage explicitly with the philosophy of his own time. But if he was aware at least in a general way of the trend that I referred to at the beginning of this paragraph, that would give more point to his refusal to play the game of appealing to predecessors. In Bett forthcoming b I may have exaggerated Sextus' isolation from his own time and place. 
As for the Methodists, the other group with which he admits some common ground, two things may be said. First, they would not generally be counted as philosophers (of any sort), and so the risks involved in being associated with philosophers would not have applied in their case. Second, whether or not the Methodists were in fact free from all doctrine, ${ }^{57}$ Sextus focuses exclusively on their role as practitioners who follow the way things appear; while, as we saw, he does not suggest that they are exactly the same as the sceptics, he takes the trouble to paint them in a light that will make them look as little like philosophers ${ }_{\mathrm{D}}$ as possible. It is therefore consistent with the aims that I have tentatively ascribed to Sextus that the Methodists, as he portrays them, should come out as the most favored among all the thinkers he considers in this part of the book..$^{58}$

57. This is a delicate and complicated question; see Frede 1982, Allen 2010.

58. I would like to thank an anonymous reader for the journal, whose comments on an earlier version prompted some rethinking and, I hope, a clearer focus in the paper, especially the final section. 


\section{BIBLIOGRAPHY}

ALLEN, J. 2010: «Pyrrhonism and Medicine», in R. Bett (ed.), 2010, p. 232-248.

ANNAS, J. \& J. BARNES 1994 (ed. \& tr.): Sextus Empiricus. Outlines of Scepticism, Cambridge, 1994.

BETT, R. 1990: «Carneades' Distinction between Assent and Approval», The Monist, 73/1 (1990), p. 3-20. 2000: Pyrrho, his Antecedents and his Legacy, Oxford, 2000.

2006: «Socrates and Skepticism», in S. Ahbel-Rappe \& R. Kamtekar (ed.), $A$ Companion to Socrates, Malden-Victoria-Oxford, p. 298-311 (Blackwell Companions to Philosophy, 34). 2010 (ed.): The Cambridge Companion to Ancient Scepticism, Cambridge, 2010 (Cambridge Companions to Philosophy).

2013: «The Pyrrhonist's Dilemma: What to write if you have nothing to say», in M. Erler \& J.E. Heßler (ed.), Argument und literarische Form in Antiker Philosophie: Akten des 3. Kongresses der Gesellschaft für antike Philosophie 2010, Berlin-Boston, 2013, p. 389-410 (Beiträge zur Altertumskunde, 320). 2015: «Pyrrhonism in Diogenes Laertius », in K. Vogt (ed.) 2015a, p. 75-104. forthcoming a: «The Cyrenaics», in D. Machuca \& B. Reed (ed.), Skepticism: From Antiquity to the Present, London.

forthcoming b: «Skepticism», in W. Johnson and D. Richter (ed.), The Oxford Handbook to the Second Sophistic, Oxford.

BonazZI, M. 2011: «A Pyrrhonian Plato? Again on Sextus on Aenesidemus on Plato», in D. Machuca (ed.), 2011, p. 11-26.

Boys-STONES, G. 2001: Post-Hellenistic Philosophy: a study of its development from the Stoics to Origen, Oxford, 2001.

Brittain, C. 2001: Philo of Larissa: The Last of the Academic Sceptics, Oxford, 2001 (Oxford Classical Monographs). 2006 (ed. \& tr.): Cicero. On Academic Scepticism, Indianapolis-Cambridge, 2006.

Brittain, C. \& J. Palmer 2001: «The New Academy's Appeals to the Presocratics», Phronesis, 46/1 (2001), p. 38-72.

BRoChard, V. 1887: Les Sceptiques grecs, Paris, 1887.

Decleva CAizzi, F. 1992: "Aenesidemus and the Academy», The Classical Quarterly, 42/1 (1992), p. 176-189.

Frede, M. 1982: «The Method of the So-Called Methodical School of Medicine», in J. Barnes, J. Brunschwig, M. Burnyeat \& M. Schofield (ed.), Science and Speculation: Studies in Hellenistic Theory and Practice, Cambridge, 1982, p. 1-23.

1997: «The Sceptic's Two Kinds of Assent and the Question of the Possibility of Knowledge», in M. Burnyeat \& M. Frede (ed.), The Original Sceptics: A Controversy, Indianapolis-Cambridge, 1997, p. 127-151.

FurLEY, D. 1993: «Democritus and Epicurus on Sensible Qualities», in J. Brunschwig \& M. Nussbaum (ed.), Passions and Perceptions: Studies in Hellenistic Philosophy of Mind. Proceedings of the Fifth Symposium Hellenisticum, Cambridge, 1993, p. 72 94.

HANKINSON, R. 2010: «Aenesidemus and the Rebirth of Pyrrhonism», in R. Bett (ed.), 2010, p. 105-119.

Holford-STREVENS, L. 1997: «Favorinus: The Man of Paradoxes», in M. Griffin and J. Barnes (ed.), Philosophia Togata. II, Plato and Aristotle at Rome, Oxford, 1997, p. 188-217. 


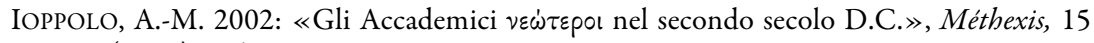
(2002), p. 45-70.

2009: La testimonianza di Sesto Empirico sull Accademia scettica, Napoli, 2009 (Elenchos, 53).

JounnNa, J. 2009: «Médecine et philosophie: sur la date de Sextus Empiricus et celle de Diogène Laërce à la lumière du Corpus Galénique», Revue des études grecques, 122/2 (2009), p. 359-390.

LÉVY, C. 2010: «The Sceptical Academy: Decline and Afterlife», in R. Bett (ed.), 2010, p. 81-104.

LONG, A. 1988: «Socrates in Hellenistic Philosophy», Classical Quarterly, 38/1 (1988), p. $150-171$.

MACHUCA, D. 2011 (ed.): New Essays on Ancient Pyrrhonism, Leiden, 2011 (Philosophia antiqua, 126).

MANSFELD, J. 1995: «Aenesidemus and the Academics», in L. Ayres (ed.), The Passionate Intellect: essays on the transformation of classical traditions, presented to Professor I. G. Kidd, New Brunswick-London, 1995, p. 235-248 (Rutgers University Studies in Classical Humanities, 7).

O'KeEFE, T. 2011: «The Cyreniacs vs. the Pyrrhonists on Knowledge of Appearances», in D. Machuca (ed.), 2011, p. 27-40.

PéreZ-JeAn, B. 2005: Dogmatisme et scepticisme: L'héraclitisme d'Énésidème, Villeneuve d'Ascq, 2005 (Philosophie ancienne).

Perin, C. 2013: «Making Sense of Arcesilaus», Oxford Studies in Ancient Philosophy, 45 (2013), p. 313-340.

POLITO, R. 2004: The Sceptical Road: Aenesidemus' appropriation of Heraclitus, Leiden, 2004 (Philosophia antiqua, 96).

SCHOfIELD, M. 2007: « Aenesidemus: Pyrrhonist and "Heraclitean"», in A.-M. Ioppolo \& D. Sedley (ed.), Pyrrhonists, Patricians, Platonizers: Hellenistic Philosophy in the Period 155-86 BC: Tenth Symposium Hellenisticum, Napoli, p. 271-338 (Elenchos, 47).

SEDLEY, D. 1989: « Philosophical Allegiance in the Greco-Roman World », in M. Griffin and J. Barnes (eds.), Philosophia Togata: Essays on Philosophy and Roman Society, Oxford, 1989, p. 97-119.

1992: «Sextus Empiricus and the Atomist Criteria of Truth», Elenchos, 13 (1992), p. $19-56$.

2012 (ed.): The Philosophy of Antiochus, Cambridge, 2012.

SPINELLI, E. 2000: «Sextus Empiricus, the Neighbouring Philosophies and the Sceptical Tradition», in J. Sihvola (ed.), Ancient Scepticism and the Sceptical Tradition, Helsinki, 2000, p. 35-61 (Acta philosophica Fennica, 66).

Thorsrud, H. 2010: «Arcesilaus and Carneades», in R. Bett (ed.), 2010, p. 58-80.

Tuominen, M. 2009: The Ancient Commentators on Plato and Aristotle, Berkeley, 2009 (Ancient philosophies, 6).

VIANO, C. 2002: «"Énésidème selon Héraclite”: la substance corporelle du temps», Revue philosophique de la France et de létranger, 127/2 (2002), p. 141-158.

VogT, K. (ed.) 2015a: Pyrrhonian Skepticism in Diogenes Laertius: Introduction, Text, Translation, Commentary and Interpretative Essays, Tübingen, 2015 (Scripta Antiquitatis Posterioris ad Ethicam Religionemque pertinentia [SAPERE], 25) 2015b: «Introduction», in K. Vogt (ed.) 2015a, p. 3-15.

WARREN, J. 2015: «Precursors of Pyrrhonism: DL 9.67-73», in K. Vogt (ed.) 2015a, p. $105-122$. 